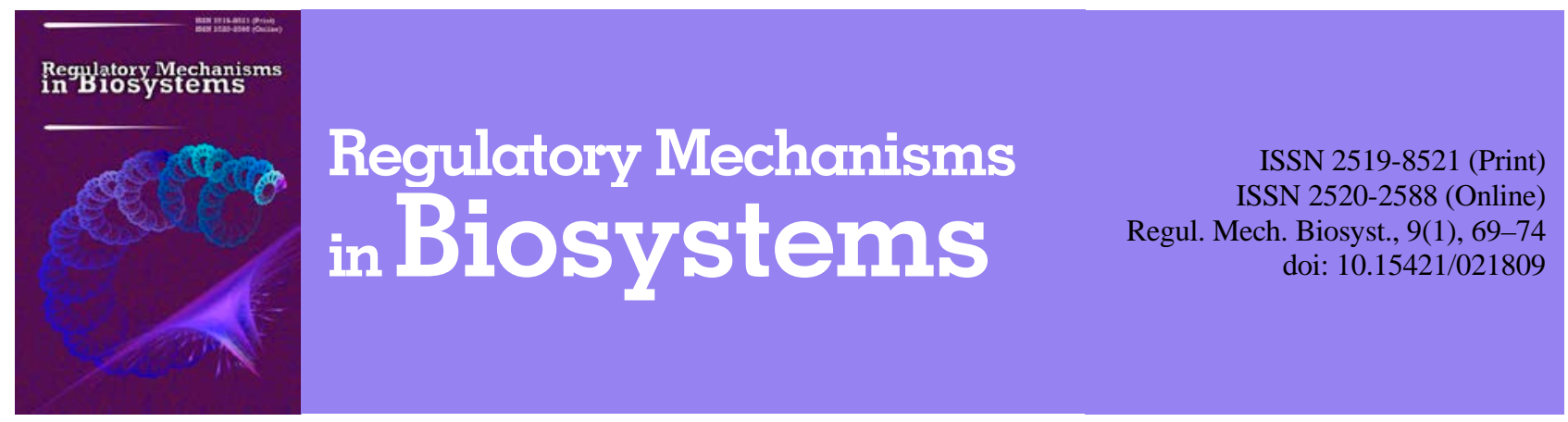

\title{
Strains of soil microorganisms promising for the creation of a complex plant protection product against mycoses and harmful insects
}

\author{
O. A. Drehval, A. A. Dreus, N. V. Cherevach, T. V. Sklyar \\ Oles Honchar Dnipro National University, Dnipro, Ukraine
}

Article info

Received 17.01.2018

Received in revised form

12.02.2018

Accepted 26.02.2018

Oles Honchar Dnipro National University, Gagarin ave., 72,

Dnipro, 49010, Ukraine.

Tel.: +38-056-760-85-14.

E-mail: microviro@ukr.net
Drehval, O. A., Dreus, A. A., Cherevach, N. V., \& Sklyar, T. V. (2018). Strains of soil microorganisms promising for the creation of a complex plant protection product against mycoses and harmful insects. Regulatory Mechanisms in Biosystems, 9(1), 69-74. doi: 10.15421/021809

We evaluated the antagonistic activity of 23 strains of Bacillus spp. against phytopathogenic fungi Fusarium oxysporum, F. culmorum, F. moniliforme, Cladosporium herbarum, Alternaria alternata and Aspergillus niger. The antagonistic activity was tested by agar diffusion (the method of blocks). For determining the influence of bacteria on barley plants , ardent seeds were treated by cultural liquid (dilution $1: 10$ ) for 2 hours and germinated in Petri dishes on moist filter paper. The fungistatic effect of Bacillus spp. separately and in combination with entomopathogens (in equal ratio) was determined by the level of inhibition of the fungi Fusarium spp. on a solid nutrient medium with $5 \%$ of the culture liquid. Insecticidal activity of microorganisms was determined in the model experiments by the percentage of death of the caterpillar Archips podana Scop. Strains of Bacillus sp. KMB-3 and Bacillus sp. KMB-6 inhibited the growth of all test cultures (zones of growth inhibition 11.4-30.6 and 11.5-29.4 mm, respectively). We established the absence of antagonism between selected strains and entomopathogenic bacteria Bacillus thuringiensis IMB-7186, fungi Beauveria bassiana IMB-F-100043. We found that treatment of barley seeds with culture liquids of Bacillus sp. KMB-3 and Bacillus sp. KMB-6 didn't have a negative effect on the morphometric indices and dry weight of seedlings. We established that the highest percentage of growth inhibition of F. culmorum IMB-F-50716 was provided by a complex of Bacillus sp. KMB-3, B. bassiana IMB-F-100043 and B. thuringiensis IMB-7186, whose action was at the same level as the action of monoculture Bacillus sp. KMB-3 (85.4\% and $84.7 \%$, respectively). The highest percentage inhibition of growth of $F$. oxysporum IMB-F-54201 was provided by a complex of strains of Bacillus sp. KMB-3 and B. bassiana IMB-F-100043, whose effect was slightly inferior to that of the monoculture Bacillus sp. KMB-3 (68.4\% and 75.1\%, respectively). The insecticidal activity of complexes Bacillus sp. KMB-3, B. bassiana IMB-F-100043, B. thuringiensis IMB-7186 or Bacillus sp. KMB-6, B. bassiana IMB-F-100043, $B$. thuringiensis IMB-7186 insignificantly differed from that of the complex entomopathogens B. bassiana IMB-F-100043 and $B$. thuringiensis IMB-7186 (71.1\%, 73.3\% death versus $80.0 \%)$. The selected microbial complexes can be considered as promising for the development of a preparation for the protection of plants against fungal diseases and harmful insects.

Keywords: antifungal action; Bacillus sp.; biocontrol; plant diseases; phytotoxicity; insecticidal activity

\section{Штами грунтових мікроорганізмів, перспективні для створення комплексного препарату захисту рослин від мікозів та шкідливих комах}

\author{
О. А. Дрегваль, А. А. Дреус, Н. В. Черевач, Т. В. Скляр \\ Дніпровський наиіональний університет імені Олеся Гончара, Дніпро, Украӥна
}

Оцінено антагоністичну активність 23 штамів Bacillus spp. відносно фітопатогенних грибів Fusarium oхуsporum, F. culmorum, F. moniliforme, Cladosporium herbarum, Alternaria alternata та Aspergillus niger. Антагоністичну активність перевіряли методом дифузії в агар за діаметром зон затримання росту навколо блоків. Для визначення впливу бактерій на рослини ярого ячменю насіння обробляли культуральною рідиною (розведення $1: 10$ ) упродовж двох годин і пророщували в чашках Петрі на зволоженому фільтрувальному папері. Фунгістатичну дію Bacillus spp. окремо та в комплексі з ентомопатогенами (в однаковому співвідношенні) визначали за рівнем пригнічення грибів Fusarium spp. на щільному живильному середовищі, до складу якого входило 5\% культуральної рідини. Інсектицидну активність мікроорганізмів визначали в модельних експериментах за відсотком загибелі гусениць Archips podana Scop. Відібрано штами Bacillus sp. KMB-3 та Bacillus sp. КMB-6, що пригнічували ріст усіх досліджуваних тест-культур. Установлено відсутність антагонізму між відібраними штамами та ентомопатогенними бактеріями Bacillus thuringiensis IMB-7186 і грибами Beauveria bassiana IMB-F-100043. Показано, що обробка насіння ярого ячменю культуральними рідинами Bacillus sp. KMB-3 та Bacillus sp. KMB-6 негативно не впливала на морфометричні показники та суху вагу проростків. Найбільший відсоток інгібування росту F. culmorum IMB-F-50716 забезпечив комплекс Bacillus sp. KMB-3, B. bassiana IMB-F100043. і B. thuringiensis IMB-7186, дія якого була на рівні дії монокультури Bacillus sp. KMB-3 (85,4\% та 84,7\% відповідно). Найбільше пригнічення росту F. охуsporum 54201 забезпечив комплекс Bacillus sp. KMB-3 і B. bassiana IMB-F-100043, дія якого незначно поступалася дії 
монокультур (68,4\% та 75,1\% відповідно). У модельних дослідах інсектицидна активність комплексів Bacillus sp. KMB-3, B. bassiana IMB-F100043, B. thuringiensis IMB-7186 або Bacillus sp. KMB-6, B. bassiana IMB-F-100043, B. thuringiensis IMB-7186 відносно гусениць Archips podana Scop. незначно відрізнялася від дії ентомопатогенів B. bassiana IMB-F-100043 і B. thuringiensis IMB-7186 (71,1\% та 73,3\% загибелі проти 80,0\%). Підібрані мікробні комплекси можуть бути використані для розроблення біопрепарату захисту рослин від грибкових хвороб і шкідників.

Ключові слова: антифунгальна дія; Bacillus spp.; біоконтроль; хвороби рослин; фітотоксичність; інсектицидна активність

\section{Ветуп}

Хімічні пестициди широко застосовують для захисту сільськогосподарських рослин від збудників захворювань і комах-шкідників. Це один із найважливіших елементів інтенсивних сільськогосподарських технологій, спрямованих на отримання високих і стабільних врожаїв рослин (Iutynska \& Ponomarenko, 2010). Проте хімічні препарати екологічно небезпечні, оскільки повільно розкладаються, продукти їх розпаду потрапляють у грунт і негативно впливають на біоту (Meena \& Kanwar, 2015). У результаті інтенсивного застосування пестицидів знижується чисельність і життєздатність грунтових сапрофітних мікроорганізмів, і навпаки, підвищується вміст шкідливих організмів, що викликає поступове зниження родючості грунтів та зменшення виробництва сільськогосподарської продукції. Необхідність отримання екологічно чистої продукції вимагає розширення досліджень, пов'язаних із розробленням систем біологічного захисту, що не порушують екологічної рівноваги грунту, сприяють поліпшенню його фітосанітарного стану (Iutynska \& Ponomarenko, 2010; Hollensteiner et al., 2017).

Серед антагоністів фітопатогенних мікроорганізмів слід відмітити представників роду Bacillus, які продукують різні антимікробні речовини, такі як циклічні ліпопептиди, а також літичні ферменти та хітинази (Alvarez et. al., 2012; Ji et al., 2013; Meena \& Kanwar, 2015; Yamamoto et al., 2015; Bodhankar et al., 2017; Dimkić et al., 2017; Molinatto et al., 2017; Rishad et al., 2017). Ліпопептиди, які продукуються B. subtilis, B. amyloliquefaciens, B. pumilus (мікосубтилін, фенгіцини А і В, ітурин), проявляють антифунгальну дію, тоді як сурфактин має широкий спектр антибактеріальної дії (Ji et al., 2013; Khong et al., 2013; Meena \& Kanwar, 2015). Kрім того, широко розповсюджені у грунті бактерії B. amyloliquefaciens синтезують амілолізин, який не належить до ліпопептидів і пригнічує ріст переважно грампозитивних бактерій (Chen et al., 2016).

Переваги циклічних ліпопептидів порівняно з хімічними засобами захисту рослин - низька токсичність, високий ступінь біодеградації та безпечність для навколишнього середовища (Meena \& Kanwar, 2015; Chen et al., 2016). Серед інших представників роду Bacillus слід відмітити широко відомий ентомопатогенний мікроорганізм B. thuringiensis, деякі штами якого здійснювали антагоністичний вплив на фітопатогенні гриби роду Verticillum. Автори припускають, що значний внесок в антифунгальну дію, крім вторинних метаболітів, вносять міколітичні хітинази, які продукуються цими штамами (Hollensteiner et al., 2017). Iз ризосфери кукурудзи нещодавно виділено штам Lysinibacillus sphaericus, який крім ларвіцидних метаболітів продукував 2-пентил-4-хінолінкарбонову кислоту, що проявляє антифунгальну дію різного ступеня проти фітопатогенних грибів Alternaria alternata, Curvularia lunata, Aspergillus sp., Sclerotinia sp., Bipolaris spicifera, Trichophyton sp. (Naureen et al., 2017). Грунтові штами бацил входять до складу ризосфери та не тільки захищають кореневу систему від збудників хвороб, a i продукують біологічно-активні речовини, що стимулюють ріст і розвиток рослин, такі як індолілоцтова кислота, сприяють солюбілізації фосфатів і силікатів, а також індукують підвищення резистентності рослин до збудників мікозів (Khong et al., 2013; Yamamoto et al., 2015; Hollensteiner et al., 2017; Naureen et al., 2017). На їх основі розробляються біологічні препарати для захисту та поліпшення живлення сільськогосподарських рослин. Більшість розроблених мікробних препаратів для захисту рослин від хвороб і шкідників створено на основі монокультур мікроорганізмів. Останнім часом зусилля науковців спрямовані на створення мікробних препаратів комплексної дії на основі асоціацій мікроорганізмів (Srivastava et al., 2010; Egamberdieva et al., 2016, 2017).

Автори статті розробили комплексний інсекто-акарицидний мікробний препарат Бактофунгін-LS на основі ентомопатогенних мікроорганізмів B. thuringiensis IMB-7186 та Beauveria bassiana IMB-F-100043, який показав високу активність проти широкого спектра комах-шкідників (Drehval et al., 2015). Враховуючи потреби сільськогосподарського виробництва щодо збереження врожаю, доцільно розширити сфери застосування цього препарату не тільки проти шкідників, а і проти збудників грибних хвороб.

Мета цієї статті - виділення бактерій роду Bacillus - антагоністів фітопатогенних грибів, перевірка відсутності фітотоксичності виділених культур, визначення взаємовідносин бактерій-антагоністів 3 ентомопатогенними мікроорганізмами, що входять до складу бактофунгіну, дослідження фунгістатичної дії комплексів антагоністів фітопатогенів та ентомопатогенів відносно грибів роду Fusarium, а також інсектицидної активності відносно гусениць Archips podana Scop.

\section{Матеріал і методи досліджень}

Антагоністичну активність штамів грунтових бактерій відносно фітопатогенних грибів перевіряли методом дифузії в агар за діаметром зон затримання росту навколо блоків. Як тест-культури використано штами фітопатогенних грибів із колекції відділу фізіології та систематики мікроміцетів IMB HАН України Fusarium oxysporum IMB-F-54201, F. culmorum IMB-F-50716, Cladosporium herbarum IMB-F-16878, а також штами з колекції культур мікроорганізмів кафедри мікробіології, вірусології та біотехнології ДНУ імені Олеся Гончара, виділені зі зразків грунту, ураженого насіння та плодів: F. охуsporum KMB-F-12, F. moniliforme KMB-F-23, Alternaria alternata KMB-F-16, Aspergillus niger KMB-F-25. Фітопатогенні гриби вирощували на картопляному агарі з $1 \%$ глюкози. Взаємовідносини бактерій-антагоністів з ентомопатогенними мікроорганізмами визначали вищезгаданим методом дифузії в агар.

Для перевірки відсутності фітотоксичної дії штамів на рослини ярого ячменю сорту Кристалія бактерії вирощували у м'ясопептонному бульйоні (МПБ) на мікробіологічній качалці (200 об./хв) за $29{ }^{\circ} \mathrm{C}$ три доби. Насіння ячменю (100 насінин) обробляли культуральною рідиною у розведенні $1: 10$ упродовж двох годин і пророщували в чашках Петрі на зволоженому фільтрувальному папері. На четверту добу досліду визначали відсоток пророслого насіння, довжину та суху масу коренів і надземної частини рослин. Як контроль використовували насіння, оброблене стерильною водопровідною водою.

Для визначення фунгістатичної дії антагоністів та ентомопатогенів окремо кожного та в комплексі (у рівних співвідношеннях) культуральні рідини мікроорганізмів вносили у розплавлене живильне середовище Чапека (5\% від об'єму) в чашки Петрі, на поверхню якого після застигання розміщували блок 10-добової культури грибів F. охуsporum IMB-F-54201 або F. culmorum IMB-F50716. Визначали відсоток інгібування росту грибів на шосту добу порівняно 3 контролем (середовищем без культуральної рідини).

Інсектицидну активність культуральних рідин мікроорганізмів (розведення $1: 10)$ визначали у модельних дослідах за відсотком загибелі гусениць Archips podana Scop. Контролем слугували комахи, корм яких обробляли водопровідною водою. Статистичну обробку даних здійснювали за допомогою комп'ютерної програми Statistica 6 (StatSoft Inc., USA). Достовірність відмінностей результатів визначали із застосуванням ANOVA.

\section{Результати}

Зі зразків грунту чорнозему звичайного виділено 23 ізоляти грампозитивних аеробних і факультативно-анаербних споротвірних бактерій, які попередньо віднесено до роду Bacillus, та досліджено на антагоністичну активність відносно штамів фітопатоген- 
них грибів - збудників фузаріозу (F. охуsporum KMB-F-12, F. oxysporum IMB-F-54201, F. culmorum IMB-F-50716, F. moniliforme KMB-F-23), альтернаріозу (A. alternata KMB-F-16), чорної цвілі (A. niger KMB-F-25), кладоспоріозу (C. herbarum IMB-F-16878). Із 23 ізолятів 14 проявили фунгістатичну дію (табл. 1).

Найперспективнішими за спектром дії виявилися штами КМВ-3 та КМB-6, які пригнічували ріст усіх перевірених тест-культур, також із дещо меншим спектром високу антагоністичну дію проявили штами KMB-5 та KMB-8. Серед перевірених тест-культур найчутливішими до дії виділених штамів бактерій виявилися $A$. alternata KMB-F-16, A. niger KMB-F-25 та C. herbarum IMB-F-16878, найстійкішими -F. oxysporum KMB-F-12 i F. oxysporum IMB-F-54201 (рис. 1).
Оскільки основна мета дослідження - пошук мікробів-антагоністів для створення комплексного біопрепарату для захисту рослин від шкідників і хвороб, здійснено перевірку взаємовідношення відібраних вищезгаданих штамів антагоністів та ентомопатогенних бактерій B. thuringiensis IMB-7186 та грибів B. bassiana IMBF-100043 - компонентів біопрепарату Бактофунгін-LS (рис. 2).

Усі досліджені штами не пригнічували ріст B. thuringiensis IMB-7186, три штами (KMB-3, KMB-5, KMB-6) також не пригнічували ріст $B$. bassiana IMB-F-100043, штам KMB-8 показав незначне інгібування росту $B$. bassiana. Враховуючи активність i спектр дії виділених антагоністів, для подальшої роботи обрано два штами бацил (KMB-3 та КMB-6).

Таблиця 1

Антагоністична активність штамів бактерій роду Bacillus до фітопатогенних грибів (n=8)

\begin{tabular}{|c|c|c|c|c|c|c|c|}
\hline \multirow{2}{*}{$\begin{array}{c}\text { Штами } \\
\text { бактерій }\end{array}$} & \multicolumn{7}{|c|}{ Діаметр зони пригнічення росту тест-культур, мм } \\
\hline & $\begin{array}{c}\text { Fusarium xysporum } \\
\text { KMB-F-12 }\end{array}$ & $\begin{array}{l}\text { Fusarium oxysporum } \\
\text { IMB-F-54201 }\end{array}$ & $\begin{array}{l}\text { Fusarium culmorum } \\
\text { IMB-F-50716 }\end{array}$ & $\begin{array}{c}\text { Fusarium moniliforme } \\
\text { KMB-F-23 }\end{array}$ & $\begin{array}{c}\text { Alternaria alternata } \\
\text { KMB-F-16 }\end{array}$ & $\begin{array}{l}\text { Aspergillus niger } \\
\text { KMB-F-25 }\end{array}$ & $\begin{array}{c}\text { Cladosporium herbarum } \\
\text { IMB-F-16878 }\end{array}$ \\
\hline KMB-1 & 0 & $13,2 \pm 0,3$ & 0 & $11,2 \pm 0,3$ & 0 & 0 & 0 \\
\hline KMB-2 & 0 & 0 & $20,6 \pm 1,0$ & $20,4 \pm 0,8$ & $24,0 \pm 0,7$ & $20,2 \pm 0,5$ & $26,1 \pm 1,1$ \\
\hline KMB-3 & $13,3 \pm 0,3$ & $11,4 \pm 0,3$ & $18,5 \pm 0,7$ & $21,5 \pm 0,6$ & $30,6 \pm 1,2$ & $24,2 \pm 0,7$ & $28,3 \pm 2,0$ \\
\hline KMB-4 & $12,4 \pm 0,4$ & 0 & $13,3 \pm 0,5$ & 0 & 0 & 0 & $15,2 \pm 0,8$ \\
\hline KMB-5 & 0 & $17,5 \pm 0,7$ & $21,4 \pm 1,2$ & $19,6 \pm 0,5$ & $28,5 \pm 0,9$ & $25,1 \pm 0,9$ & $27,4 \pm 1,0$ \\
\hline KMB-6 & $11,5 \pm 0,2$ & $15,2 \pm 0,9$ & $23,2 \pm 1,5$ & $20,5 \pm 0,7$ & $27,2 \pm 0,6$ & $29,4 \pm 0,6$ & $23,5 \pm 0,9$ \\
\hline KMB-7 & $15,3 \pm 0,8$ & $15,1 \pm 0,6$ & 0 & $19,3 \pm 0,2$ & $27,3 \pm 0,8$ & $19,5 \pm 0,3$ & $26,5 \pm 0,5$ \\
\hline KMB-8 & 0 & $18,5 \pm 0,8$ & $20,0 \pm 0,9$ & $20,7 \pm 0,3$ & $25,5 \pm 0,4$ & $25,5 \pm 0,8$ & $28,1 \pm 0,6$ \\
\hline KMB-9 & $16,2 \pm 0,9$ & 0 & $10,5 \pm 0,1$ & 0 & 0 & 0 & 0 \\
\hline KMB-10 & $12,0 \pm 0,3$ & 0 & 0 & 0 & 0 & 0 & 0 \\
\hline KMB-11 & 0 & 0 & 0 & 0 & $12,5 \pm 0,2$ & $9,5 \pm 0,2$ & $13,2 \pm 0,3$ \\
\hline KMB-12 & $10,5 \pm 0,2$ & $10,3 \pm 0,2$ & $14,5 \pm 0,6$ & 0 & $12,0 \pm 0,5$ & 0 & 0 \\
\hline KMB-13 & 0 & $11,2 \pm 0,3$ & 0 & $12,0 \pm 0,4$ & 0 & $10,4 \pm 0,1$ & 0 \\
\hline KMB-14 & $12,2 \pm 0,4$ & $12,4 \pm 0,5$ & $13,3 \pm 0,5$ & $10,0 \pm 0,6$ & 0 & 0 & $13,3 \pm 0,4$ \\
\hline
\end{tabular}
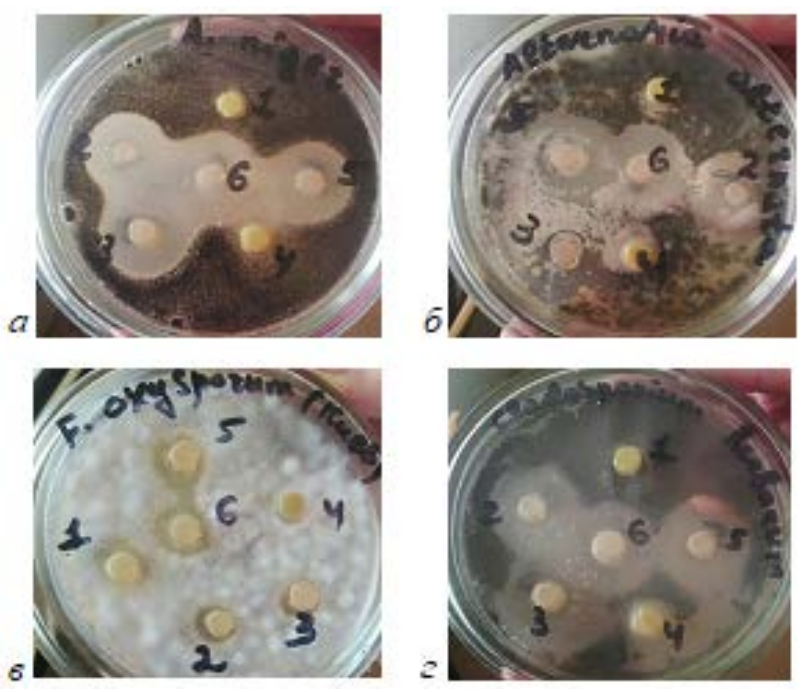

Рис. 1. Вплив штамів бактерій роду Bacillus на ріст фітопатогенних грибів: $a$-Aspergillus niger KMB-F-25; 6-Alternaria alternata KMB-F-16; 8 - Fusarium oxysporum IMB-F-54201; 2-Cladosporium herbarum IMB-F-16878; 1-6- номери штамів-антагоністів

Таблиця 2

Вплив штамів бактерій-антагоністів на формування проростків ярого ячменю сорту Кристалія ( $\mathrm{n}=100)$

\begin{tabular}{lccc}
\hline \multicolumn{1}{c}{$\begin{array}{c}\text { Варіант } \\
\text { обробки }\end{array}$} & $\begin{array}{c}\text { Частка пророслого Середня довжина Середня довжина } \\
\text { насіння, \% }\end{array}$ & пагонів, мм & коренів, мм \\
\hline Bacillus sp. КMB-3 & $91,0 \pm 1,9$ & $38,8 \pm 2,0$ & $261,0 \pm 6,3$ \\
Bacillus sp. KMB-6 & $84,0 \pm 6,6$ & $38,3 \pm 2,8$ & $246,7 \pm 18,4$ \\
Контроль & $95,0 \pm 2,2$ & $43,1 \pm 2,9$ & $264,7 \pm 26,4$ \\
\hline
\end{tabular}

Розробляючи біопрепарати для захисту рослин, необхідно здійснювати випробування на фітотоксичність мікробних культур. Наші дослідження на рослинах ячменю ярого сорту Кристалія показали відсутність фітотоксичної дії Bacillus sp. KMB-3 та Bacillus sp. KMВ-6 за морфометричними показниками та сухою вагою проростків. Незначні різниці відсотка пророслого насіння, довжини пагонів і коріння проростків та їх сухої ваги статистично не достовірні (табл. 2, рис. 3).
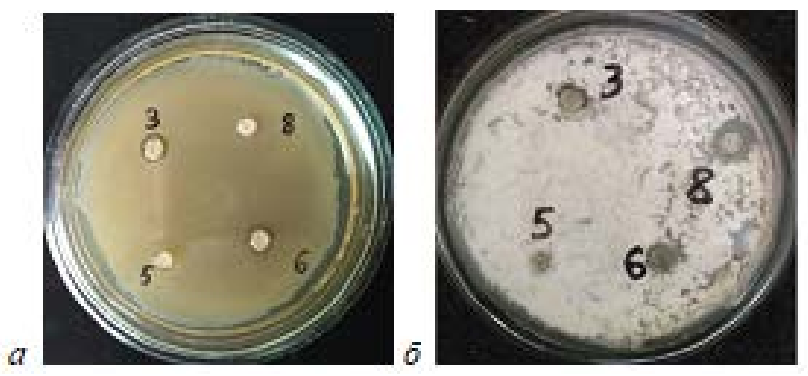

Pис. 2. Вплив найактивніших штамів-антагоністів фітопатогенних грибів на ріст ентомопатогенних мікроорганізмів: $a-$ Bacillus thuringiensis IMB-7186; $\sigma$ - Beauveria bassiana

IMB-F-100043; 3, 5, 6, 8- номери штамів-антагоністів

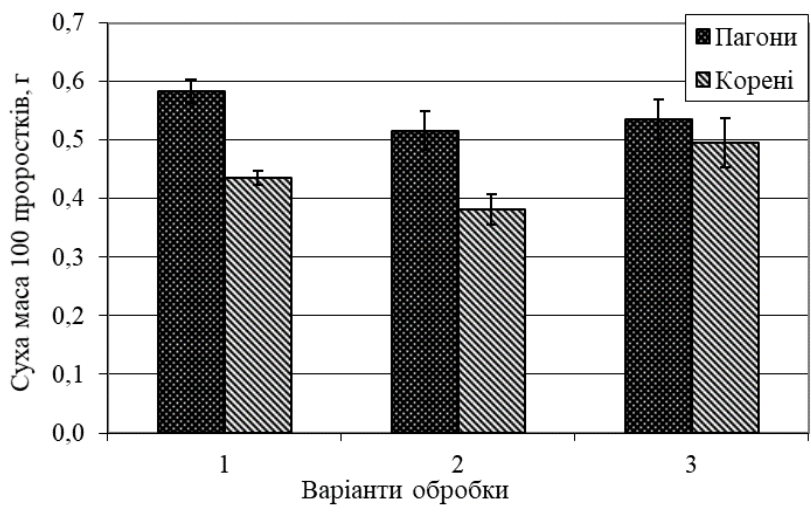

Рис. 3. Суха маса коренів та пагонів ярого ячменю сорту Кристалія за обробки культуральною рідиною бактерій: 1 - Bacillus sp.

KMB-3; 2 - Bacillus sp. KMB-6; 3 - контроль ( $=100)$ 
Для створення комплексного препарату важливо дослідити спільну дію всіх компонентів мікробного комплексу на збудників грибних хвороб рослин. Випробувано дію комплексів на гриби роду Fusarium, оскільки, з одного боку, вони завдають найбільших збитків сільськогосподарському виробництву, з іншого - ці гриби виявилися менш чутливими до дії виділених антагоністів.

Попередня перевірка антагоністичних властивостей ентомопатогенних мікроорганізмів показала відсутність фунгістатичної діï B. thuringiensis IMB-7186 i, навпаки, суттєве інгібування росту фузаріїв культурою B. bassiana IMB-F-100043. Тому дію мікроб- них комплексів, що складалися зі штаму-антагоніста та ентомопатогена B. bassiana IMB-F-100043 і штаму-антагоніста та штамів B. bassiana IMB-F-100043 і B. thuringiensis IMB-7186 порівнювали 3 дією монокультур штамів-антагоністів (табл. 3, 4).

Найбілыший відсоток інгібування росту F. culmorum IMB-F50716 забезпечив комплекс Bacillus sp. KMB-3, B. bassiana IMB-F100043 і B. thuringiensis IMB-7186, дія якого була на рівні дії монокультури Bacillus sp. KMB-3. Найбілыше пригнічення росту F. oxysporum IMB-F-54201 забезпечив комплекс Bacillus sp. KMB-3 i B. bassiana IMB-F-100043, дія якого дещо поступалася дії монокультур.

Таблиця 3

Комплексна дія штамів-антагоністів та B. thuringiensis IMB-7186 i B. bassiana IMB-F-100043 на лінійний ріст F. culmorum 50716 (n = 8)

\begin{tabular}{|c|c|c|c|c|}
\hline Варіант досліду & $\begin{array}{l}\text { Діаметр колонії, мм } \\
\text { третя доба }\end{array}$ & $\begin{array}{l}\text { Інгібування росту, } \% \\
\text { третя доба }\end{array}$ & $\begin{array}{l}\text { Діаметр колонії, мм } \\
\text { шоста доба }\end{array}$ & $\begin{array}{l}\text { Інгібування росту, \% } \\
\text { шоста доба }\end{array}$ \\
\hline Контроль & $29,7 \pm 1,4$ & - & $78,5 \pm 1,9$ & - \\
\hline Bacillus sp. KMB-3 & $12,0 \pm 0,3^{* *}$ & 59,6 & $12,0 \pm 0,3 * *$ & 84,7 \\
\hline Bacillus sp. KMB-6 & $11,4 \pm 0,3^{* *}$ & 61,6 & $11,1 \pm 0,2 * * *$ & 85,9 \\
\hline B. thuringiensis IMB-7186 & $30,1 \pm 1,5$ & 0,0 & $83,2 \pm 1,1$ & 0,0 \\
\hline B. bassiana IMB-F-100043 & $10,7 \pm 0,3 * * *$ & 64,0 & $15,5 \pm 1,3^{*}$ & 80,3 \\
\hline Bacillus sp. KMB-3 + B. bassiana IMB-F-100043 & $11,3 \pm 0,3 * *$ & 62,0 & $11,5 \pm 0,3 * * *$ & 85,4 \\
\hline Bacillus sp. KMB-6 + B. bassiana IMB-F-100043 & $14,2 \pm 0,9 *$ & 52,2 & $13,7 \pm 0,3^{*}$ & 82,5 \\
\hline $\begin{array}{l}\text { Bacillus sp. KMB-3 + B. bassiana IMB-F-100043 } \\
+ \text { B. thuringiensis IMB-7186 }\end{array}$ & $11,3 \pm 0,7^{* *}$ & 62,0 & $11,3 \pm 0,2 * * *$ & 85,6 \\
\hline $\begin{array}{l}\text { Bacillus sp. KMB- } 6 \text { + B. bassiana IMB-F-100043 } \\
+ \text { B. thuringiensis IMB-7186 }\end{array}$ & $15,2 \pm 0,4^{*}$ & 48,8 & $14,8 \pm 1,2^{*}$ & 81,1 \\
\hline
\end{tabular}

Примітка: *-P <0,05, **-P <0,01, ***_- $<0,001$ відносно контролю-ростом гриба за відсутності культуральних рідин мікроорганізмів у середовищі.

Таблиця 4

Комплексна дія штамів-антагоністів та B. thuringiensis IMB-7186 i B. bassiana IMB-F-100043 на лінійний ріст F. oxysporum IMB-F-54201 (n = 8)

\begin{tabular}{|c|c|c|c|c|}
\hline Варіант досліду & $\begin{array}{l}\text { Діаметр колонії, мм } \\
\text { третя доба }\end{array}$ & $\begin{array}{l}\text { Інгібування росту, \% } \\
\text { третя доба }\end{array}$ & $\begin{array}{l}\text { Діаметр колонії, мм } \\
\text { шоста доба }\end{array}$ & $\begin{array}{l}\text { Інгібування росту, \% } \\
\text { шоста доба }\end{array}$ \\
\hline Контроль & $44,3 \pm 0,6$ & - & $85,4 \pm 0,4$ & - \\
\hline Bacillus sp. KMB-3 & $23,4 \pm 2,6^{*}$ & 47,2 & $21,3 \pm 1,3 * * *$ & 75,1 \\
\hline Bacillus sp. KMB-6 & $23,9 \pm 1,7^{*}$ & 46,1 & $25,6 \pm 1,6^{* *}$ & 70,0 \\
\hline B. thuringiensis IMB-7186 & $45,3 \pm 2,3$ & 0,0 & $87,5 \pm 1,2$ & 0,0 \\
\hline B. bassiana IMB-F-100043 & $18,9 \pm 0,7^{* *}$ & 57,3 & $21,2 \pm 3,3^{* *}$ & 75,2 \\
\hline Bacillus sp. KMB-3 + B. bassiana IMB-F-100043 & $25,5 \pm 2,9 *$ & 42,4 & $27,0 \pm 2,7^{*}$ & 68,4 \\
\hline Bacillus sp. KMB-6 + B. bassiana IMB-F-100043 & $29,8 \pm 1,4^{*}$ & 22,7 & $29,4 \pm 2,0^{*}$ & 65,6 \\
\hline $\begin{array}{l}\text { Bacillus sp. KMB-3 + B. bassiana IMB-F-100043 } \\
+ \text { B. thuringiensis IMB-7186 }\end{array}$ & $33,2 \pm 0,9^{*}$ & 25,1 & $31,4 \pm 1,3^{*}$ & 63,2 \\
\hline $\begin{array}{l}\text { Bacillus sp. KMB- } 6 \text { + B. bassiana IMB-F-100043 } \\
+ \text { B. thuringiensis IMB-7186 }\end{array}$ & $35,2 \pm 1,1^{*}$ & 20,6 & $35,4 \pm 1,5^{*}$ & 58,5 \\
\hline
\end{tabular}

Примітка: див. табл. 3.

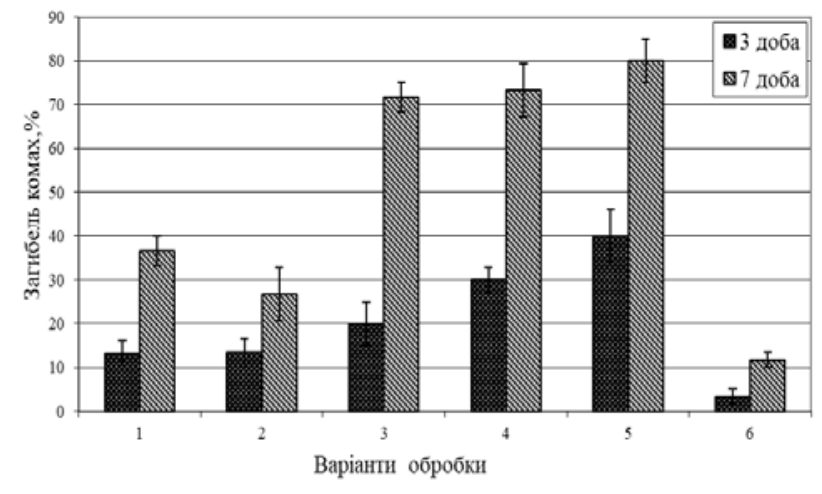

Рис. 4. Інсектицидна активність мікробних культур та їх комплексів відносно гусениць Archips podana Scop.:

1 - Bacillus sp. KMB-3; 2 - Bacillus sp. KMB-6; 3 - Bacillus sp.

KMB-3 + B. bassiana IMB-F-100043 + B. thuringiensis IMB-7186;

4-Bacillus sp. KMB-6 + B. bassiana IMB-F-100043 +

B. thuringiensis IMB-7186; 5-B. bassiana IMB-F-100043 + B. thuringiensis IMB-7186; 6 - контрольні (незаражені) комахи (n = 8)

Розробляючи склад поліфункціонального мікробного препарату, доцільно перевірити інсектицидну активність комплексів ентомопатогенів із Bacillus sp. KMB-3 або Bacillus sp. KMB-6. Дію комплексів порівнювали з інсектицидною активністю B. bassiana
IMB-F-100043 + B. thuringiensis IMB-7186 (Бактофунгін-LS) та дією штамів бацил відносно гусениць листовійки всеїдної (рис. 4).

Інсектицидна активність комплексів Bacillus sp. KMB-3, B. bassiana IMB-F-100043, B. thuringiensis IMB-7186 та Bacillus sp. KMB-6, B. bassiana IMB-F-100043, B. thuringiensis IMB-7186 незначно відрізнялася від дії ентомопатогенів B. bassiana IMB-F$100043+$ B. thuringiensis IMB-7186. Невисоку інсектицидну дію встановлено також для штаму Bacillus sp. KMB-3 (36,7\% загибелі личинок, $\mathrm{P}<0,01$ порівняно $з$ контролем).

\section{Обговорення}

Грунтові штами Bacillus spp. характеризувалися різним ступенем і спектром антифунгальної дії. Із даних літератури відомо, що бактерії роду Bacillus здатні продукувати різні антимікробні речовини, наприклад, циклічні ліпопептиди, які пригнічують ріст міцелію грибів і проростання конідій мікроміцетів. Зокрема, B. amyloliquefaciens CNU114001 продукував ліпопептид ітурин, який характеризувався активністю проти широкого спектра фітопатогенних грибів Alternaria panax, Botrytis cinerea, Colletotrichum orbiculare, Penicillium digitatum, Pyricularia grisea та Sclerotinia sclerotiorum (Ji et al., 2013). В іншому дослідженні показано, що бактерії того самого виду бацил продукують циклічні ліпопептиди сурфактин C, фенгіцини А i B, які пригнічували ріст S. sclerotiorum. Штами B. amyloliquefaciens пропонується використовувати для біоконтролю склеротиніального захворювання стовбуровою гнил- 
лю (Alvarez et al., 2012). Бактерії, які продукують сурфактин, зазвичай характеризуються антибактеріальною дією. Так, B. subtilis 6051 пригнічував ріст Pseudomonas syringae, a B. amyloliquefaciens KPS46 - Xanthomonas axonopodis pv. glycines (Meena \& Kanwar, 2015). У цьому дослідженні широкий спектр антифунгальної дії показали штами Bacillus sp. KMB-3 i Bacillus sp. KMB-6, які пригнічували ріст усіх протестованих культур фітопатогенів та не проявляли фітотоксичності.

Останнім часом у рослинництві замість препаратів на основі монокультур дослідники пропонують використовувати комплекс різних мікроорганізмів із додатковими або синергічними властивостями. Передпосівна інокуляція комплексом, що складався із симбіотичного азотфіксатора Mesorhizobium ciceri IC53 та ендофітного штаму B. subtilis NUU4, ефективніше стимулювала ріст бобової рослини Cicer arietinum L., а також утворення бульбочок, формування стручків та урожаю порівняно з інокуляцією одним азотфіксатором. Позитивний вплив мікробного комплексу автори пояснюють такими додатковими властивостями B. subtilis NUU4 як здатність до утворення індолілоцтової кислоти, солюбілізація фосфатів і зменшення прояву інфекції, спричиненої фітопатогенним грибом Fusarium solani (Egamberdieva et al., 2017). Egamberdieva et al. (2016) повідомили про синергетичний вплив комбінованої інокуляції Mesorhizobium sp. та Pseudomonas extremorientalis TSAU20 на ростові показники лікарської бобової рослини Glycyrrhiza uralensis Fish. за сольового стресу. В іншому дослідженні сумісне застосування Pseudomonas fluorescens, Trichoderma harziпатит і ендомікоризних грибів краще знижувало інфікування томатів F. oxysporum f. lycopersici, ніж інокуляція одним із цих мікроорганізмів. Комбінована інокуляція знизила важкість захворювання на 74\% у польових умовах, урожайність культури при цьому підвищилась на 20\% порівняно з контролем (Srivastava et al., 2010). У нашому дослідженні підібрані комплекси мікроорганізмів проявили фунгістатичну та інсектицидну дію та можуть застосовуватись для захисту рослин від грибкових хвороб і комах-шкідників.

Перевірка антагоністичних властивостей ентомопатогенних мікроорганізмів показала відсутність фунгістатичної дії досліджуваного штаму B. thuringiensis IMB-7186 i, навпаки, суттєве інгібування росту фузаріїв культурою B. bassiana IMB-F-100043. 3 даних літератури відомо, що деякі штами B. thuringiensis, крім інсектицидної дії, характеризуються високою антагоністичною активністю щодо фітопатогенних мікроміцетів родів Venturia, Verticillium тощо. Це зумовлено синтезом протигрибкових речовин (бацилібактину, цвітерміцину А), а також міколітичних хітиназ, що спричиняють лізис, зміни щільності, товщини та напрямку росту міцелію (Hollensteiner et al., 2017; Patyka et al., 2017). Внесений у щільне живильне середовище очищений препарат ендохітинази B. thuringiensis subsp. tenebrionis DSM-2803 пригнічував радіальний ріст Colletotrichium gloeosporioides, збудника антракнозу рослин. Автори спостерігали пряму кореляцію між концентрацією ендохітинази та рівнем інгібування росту фітопатогену (De la FuenteSalcido et al., 2016). Крім хітинази штам B. thuringiensis HD1 утворював хітинзв'язувальний білок, локалізований в оболонках спор. Цей білок посилював інсектицидну дію кристалічного білка Сry 1Ас та інгібував ріст грибів Culvularia oryzae, Aspergillus oryzae, Aspergillus parasiticus, Verticillium dahliae. Хітинзв'язувальний білок діє як синергіст хітинази, внаслідок чого відбувається інтенсивніше пригнічення росту грибів (Arora et al., 2013). Також відомо, що B. bassiana, крім активності проти комах, може виступати антагоністом відносно збудників хвороб рослин. Механізм антагоністичної дії цього гриба дослідники пов'язують зі здатністю продукувати антибіотичні речовини, а також конкуренцією за субстрат та індукцією системної резистентності рослин проти збудників захворювань рослин (Shahid et al., 2012). Отримані нами дані підтверджують здатність штаму B. bassiana IMB-F-100043 пригнічувати ріст фітопатогенних грибів, проте використаний нами штам B. thuringiensis IMB-7186 не пригнічував досліджувані гриби роду Fusarium.

Дані наших досліджень свідчать про невисоку інсектицидну активність культуральних рідин Bacillus sp. KMB-3. Із літератур- них джерел відомо, що деякі антагоністи фітопатогенних грибів, що продукують хітинолітичні ферменти, характеризуються ентомоцидною дією. Rishad et al. (2017) повідомили про виділення та очищення хітинази із B. pumilus MCB-7, що проявляла міколітичну активність відносно Aspergillus flavus, A. niger, A. fumigatus, Ceratorhiza hydrophila та Fusarium oxysporum. Цей фермент показав також ентомоцидну активність відносно личинок Scirpophaga incertulas Walker (Lepidoptera: Pyralidae), шкідника рису. Meena \& Kanwar (2015) також встановили, що супернатанти культуральних рідин штамів B. subtilis, що продукують ліпопептид сурфактин, показали високу смертність личинок і пупаріїв комарів видів Culex quinquefasciatus, Anopheles stephensi, Aedes aegypti.

\section{Висновки}

Зі зразків грунту чорнозему звичайного виділено 23 ізоляти бактерій, віднесених до роду Bacillus. Найвищу антагоністичну активність відносно фітопатогенних грибів Fusarium culmorum, F. moniliforme, F. oxysporum, Cladosporium herbarum, Aspergillus niger, Alternaria alternate показали штами Bacillus sp. KMB-3 та Bacillus sp. KMB-6. Установлено відсутність антагонізму між відібраними штамами та ентомопатогенними бактеріями Bacillus thuringiensis IMB-7186 та грибами Beauveria bassiana IMB-F100043. Обробка насіння ярого ячменю культуральними рідинами Bacillus sp. KMB-3 та Bacillus sp. KMB-6 негативно не впливала на морфометричні показники та суху вагу проростків. Підібрано мікробні комплекси, до складу яких входять один із відібраних штамів-антагоністів та ентомопатогени B. thuringiensis IMB-7186 i B. bassiana IMB-F-100043, що проявляють фунгістатичну дію до фітопатогенних грибів роду Fusarium та інсектицидну активність відносно гусениць Archips podana Scop.

\section{References}

Alvarez, F., Castro, M., Principe, F., Borioli, G., Fischer, S., Mori, G., \& G. Jofre, E. (2012). The plant-associated Bacillus amyloliquefaciens strains MEP2 18 and ARP2 3 capable of producing the cyclic lipopeptides iturin or surfactin and fengycin are effective in biocontrol of sclerotinia stem rot disease. Journal of Applied Microbiology, 112(1), 159-174.

Arora, N., Sachdev, B., Gupta, R., Vimala, Y., \& Bhatnagar, R. K. (2013). Characterization of a chitin-binding protein from Bacillus thuringiensis HD-1. PLOS ONE, 8(6), e66603.

Bodhankar, S., Grover, M., Hemanth, S., Reddy, G., Rasul, S., Yadav, S. K., Desai, S., Mallappa, M., Mandapaka, M., \& Srinivasarao, C. (2017). Maize seed endophytic bacteria: Dominance of antagonistic, lytic enzyme-producing Bacillus spp. 3 Biotech, 7(4), 232.

Chen, J. N., Wei, C. W., Liu, H. C., Chen, S. Y., Chen, C., Juang, Y. M., Lai, C. C., \& Yiang, G. T. (2016). Extracts containing CLPs of Bacillus amyloliquefaciens JN68 isolated from chicken intestines exert antimicrobial effects, particularly on methicillin-resistant Staphylococcus aureus and Listeria monocytogenes. Molecular Medicine Reports, 14(6), 5155-5163.

De la Fuente-Salcido, N. M., Casados-Vazquez, L. E., Garcia-Perez, A. P., Barboza-Perez, U. E., Bideshi, D. K., Salcedo-Hernandez, R., Garcia- Almendarez, B. E., \& Barboza-Corona, J. E. (2016). The endochitinase ChiA Btt of Bacillus thuringiensis subsp. tenebrionis DSM- 2803 and its potential use to control the phytopathogen Colletotrichum gloeosporioides. MicrobiologyOpen, 5(5), 819-829.

Dimkic, I., Stankovic, S., Nisavic, M., Petkovic, M., Ristivojevic, P., Fira, D., \& Beric, T. (2017). The profile and antimicrobial activity of Bacillus lipopeptide extracts of five potential biocontrol strains. Frontiers in Microbiology, 8, 925.

Drehval, O. A., Vlasenko, O. G., Cherevach, N. V., \& Vinnikov, A. I (2015). Vplyv mikrobnogo preparatu "Baktofungin-LS" na persykovu popelycju u kontrol'ovanyh umovah [Influence of microbial preparation "Baktofungin-LS” on peach aphid in controlled conditions]. Agroekologichnyj Zhurnal, 4, 85-89 (in Ukrainian).

Egamberdieva, D., Li, L., Lindström, K., \& Räsänen, L. A. (2016). A synergistic interaction between salt-tolerant Pseudomonas and Mesorhizobium strains improves growth and symbiotic performance of liquorice (Glycyrrhiza uralensis Fish.) under salt stress. Applied Microbiology and Biotechnology, 100(6), 2829-2841.

Egamberdieva, D., Wirth, S. J., Shurigin, V. V., Hashem, A., \& Abd Allah, E. F. (2017). Endophytic bacteria improve plant growth, symbiotic performance of chickpea (Cicer arietinum L.) and induce suppression of root rot caused by Fusarium solani under salt stress. Frontiers in Microbiology, 8, 1887. 
Hollensteiner, J., Wemheuer, F., Harting, R., Kolarzyk, A. M., Diaz Valerio, S. M., Poehlein, A., Brzuszkiewicz, E. B., Nesemann, K., Braus-Stromeyer, S. A., Braus, G. H., Daniel, R., \& Liesegang, H. (2017). Bacillus thuringiensis and Bacillus weihenstephanensis inhibit the growth of phytopathogenic Verticillium species. Frontiers in Microbiology, 7, 2171.

Iutynska, G. O., \& Ponomarenko, S. P. (eds.). (2010). Bioreguljacija mikrobnorastitel'nyh sistem [Bioregulation of microbial-plant systems]. Nichlava, Kiev (in Russian).

Ji, S. H., Paul, N. C., Deng, J. X., Kim, Y. S., Yun, B. S., \& Yu, S. H. (2013) Biocontrol activity of Bacillus amyloliquefaciens CNU114001 against fungal plant diseases. Mycobiology, 41(4), 234-242.

Khong, N. G., Randoux, B., Deravel, J., Tisserant, B., Tayeh, Ch., Coutte, F. Bourdon, N., Jacques, P., \& Reignault, P. (2013). Induction of resistance in wheat by bacterial cyclic lipopeptides. Communications in Agricultural and Applied Biological Sciences, 78(3), 479-487.

Meena, K. R., \& Kanwar, S. S. (2015). Lipopeptides as the antifungal and antibacterial agents: Applications in food safety and therapeutics. BioMed Research International, 2015, 473050.

Molinatto, G., Franzil, L., Steels, S., Puopolo, G., Pertot, I., \& Ongena, M. (2017). Key impact of an uncommon plasmid on Bacillus amyloliquefaciens subsp. plantarum S499 developmental traits and lipopeptide production. Frontiers in Microbiology, 8, 17.

Naureen, Z., Rehman, N. U., Hussain, H., Hussain, J., Gilani, S. A., Al Housni, S. K., Mabood, F., Khan, A. L., Farooq, S., Abbas, G., \& Harrasi, A. A. (2017)
Exploring the potentials of Lysinibacillus sphaericus ZA9 for plant growth promotion and biocontrol activities against phytopathogenic fungi. Frontiers in Microbiology, 8, 1477.

Patyka, T. I., Bojko, M. V., \& Patyka, M. V. (2017). Biotehnologichna polifunkcional'nist' metabolitnogo sporo-krystalichnogo kompleksu ta osoblyvosti kul'tyvuvannja Bacillus thuringiensis [Biotechnological polyfunctionality of the metabolic spore-crystalline complex and Bacillus thuringiensis cultivation features]. Mikrobiologichnyj Zhurnal, 79(2), 78-85 (in Ukrainian).

Rishad, K. S., Rebello, S., Shabanamol, P. S., \& Jisha, M. S. (2017). Biocontrol potential of halotolerant bacterial chitinase from high yielding novel Bacillus pumilus MCB-7 autochthonous to mangrove ecosystem. Pesticide Biochemistry and Physiology, 137, 36-41.

Shahid, A. A., Rau, A. Q., Bakhsh, A., \& Husnain, T. (2012). Entomopathogenic fungi as biological controllers: New insights into their virulence and pathogenicity. Archives of Biological Sciences, 64(1), 21-42.

Srivastava, R., Khalid, A., Singh, U. S., \& Sharma, A. K. (2010). Evaluation of arbuscular mycorrhizal fungus, fluorescent Pseudomonas and Trichoderma harzianum formulation against Fusarium oxysporum f. sp. lycopersici for the management of tomato wilt. Biological Control, 53(1), 24-31.

Yamammoto, S., Shiraishi, S., \& Suzuki, S. (2015). Are cyclic lipopeptides produced by Bacillus amyloliquefaciens S13-3 responsible for the plant defence response in strawberry against Colletotrichum gloeosporioides? Letters in Applied Microbiology, 60(4), 379-386. 